\title{
PERLINDUNGAN HUKUM BAGI KONSUMEN BERKAITAN DENGAN PENCANTUMAN DISCLAIMER OLEH PELAKU USAHA DALAM SITUS INTERNET (WEBSITE)
}

\section{Oleh :}

\author{
Ni Putu Ria Dewi Marheni
}

\section{Mahasiswa Magister Ilmu Hukum Universitas Udayana}

\section{ABSTRACT}

This Research is entitled "Legal Protection for Consumers Related to the Inclusion of Disclaimer by Business Owner in Website". The problems of the present study are: first, how the inclusion of disclaimer in websites in Indonesia is like; second, what the legal protection for consumers related to the inclusion of disclaimer by business owner in websites is like.

The method used in the present study is the normative legal research. The results of the study showed: first, no norm regulating disclaimer in the Act Number 11 of 2008 concerning the electronic information and transaction which specifically regulate activities in the cyberspace. However, if generally viewed from the protection for consumers in the Act Number 8 of 1999 concerning Protection for Consumers, most inclusions of disclaimer in the website is classified as exoneration clausal which is partially prepared by business agents to avoid what they are supposed to be responsible for. Second, the form of legal protection needed by consumers in the internet is still weak. However, the general legal protection for consumers may be provided through: a) Being preventive: Reliability Certification Board 'Lembaga Sertifikasi Keandalan'(LSK) which is supposed to give certification for every internet site already regulated by the Regulation of the Republic of Indonesia Number 82 of 2012 concerning the Implementation of Electronic System and Transaction which is a derivative of Article 10 clause (2) of the Act Number 11 of 2008 concerning Electronic Information and Transaction; b) being repressive: through Litigation Lane which may be done by submitting a civil suit and civil sanction based on the Act Number 11 of 2008 concerning Electronic Information and Transaction. Another alternative is through the Non Litigation lane, that is, the Arbitrate Lane, which is settled using the Alternative of Dispute Settlement.

Keywords: Disclaimer, Legal Protection, Consumer Protection, Website, Electronic Information and Transaction

\section{PENDAHULUAN}

\section{Latar Belakang}

Perilaku masyarakat secara

global telah berubah seiring dengan

perkembangan teknologi informasi dan komuikasi. Pertumbuhan

perekonomian dapat menciptakan

kesejahteraan masyarakat yang

merupakan dampak dari

pemanfaatan teknologi informasi. 
Berangkat dengan menggunakan mesin pencari di Internet para pengguna sistem elektronik yang dapat disebut juga konsumen dapat menjelajahi seluruh isi dunia, mendapatkan berbagai informasi, barang/jasa, kebutuhan sehari-hari dan juga mengetahui perkembangan teknologi di berbagai belahan bumi.

Perusahaan-perusahaan berskala kecil, menengah dan besar menggunakan teknologi internet sebagai pendukung kegiatan bisnisnya. Internet digunakan sebagai wadah untuk promosi, bisnis dan fasilitas untuk mendapatkan informasi mengenai segala hal. Pemasaran yang dulunya dilakukan secara konvensional sekarang ini banyak yang dilakukan dengan bantuan teknologi internet. Pengguna sistem elektronik / konsumen sampai saat ini banyak yang belum menyadari bahwa dalam setiap situs di Internet mencantumkan disclaimer template pada bagian lain pada lay out situs internet tersebut. Dalam situs jual beli online (e-commerce) di internet banyak dicantumkannya disclaimer yang salah satu bunyinya menjelaskan bahwa penyelenggara sistem elektronik sebagai pelaku usaha mengalihkan tanggung jawabnya ke konsumen atas kerusakan dari setiap produk yang sudah dibeli oleh konsumen.

Disclaimer dicantumkan oleh penyelenggara sistem elektronik / pelaku usaha tanpa adanya negosiasi dengan konsumen terlebih dahulu. Dari 10 situs internet yang diakses, 8 diantaranya mencantumkan disclaimer yang didalamnya mengandung pengalihan tanggung jawab penyelenggara sistem elektronik terhadap segala sesuatu hal yang mungkin akan terjadi dan berakibat merugikan konsumen. Salah satu keluhan konsumen dalam jual beli secara online (e-commerce) juga ditemukan salah satunya adalah mengenai seorang konsumen yang membeli jam tangan disebuah online shop di internet dimana permasalahan muncul ketika barang sampai ditangan konsumen ternyata hanya berupa kotak jam saja tanpa ada jam tangan padahal sebelumnya konsumen sudah melakukan pembayaran lunas ke pelaku usaha online shop tersebut, tentu saja dsini konsumen tersebut merasa kecewa 
dan dirugikan kemudian langsung menghubungi pihak online shop dan pihak online shop tidak mau bertanggung jawab atas tidak adanya jam tangan didalam kotak jam tersebut, tentu saja alasan pihak online shop tersebut dikuatkan dengan disclaimer yang telah dicantumkan sebelumnya bahwa pihak online shop tidak bertanggung jawab atas barang yang telah dikirim ke pembeli. Tentu saja disini sangat jelas dilihat bahwa penyelenggara sistem elektronik pada situs tersebut ingin mengalihkan tanggung jawabnya. Menurut Efraim Turban ${ }^{1}$ "Transaksi elektronik merupakan suatu proses jual beli atau bertukar produk, jasa dan / atau informasi melalui jaringan komputer, terutama internet dan intranet”.

Aktivitas Informasi dan Transaksi Elektronik di Indonesia sudah diundangkan berdasarkan UU No.11 Th. 2008 tentang Informasi dan Teknologi dan Peraturan Pemerintah RI No. 82 Th. 2012 tentang Penyelenggaraan Sistem dan

\footnotetext{
${ }^{1}$ Efraim Turban, et. al,2010, Electronic commerce (a managerial perspective) sixth edition, Pearson, USA, page 46.
}

Transaksi Elektronik. Undangundang ITE merupakan peraturan khusus mengatur bidang Informasi dan Transaksi Elektronik belum terdapat pengaturan mengenai kriteria-kriteria yang wajib dipatuhi oleh penyelenggara sistem elektronik/ pelaku usaha berkaitan dengan substansi dari pencantuman klausula disclaimer dalam setiap situs internet (website) sehingga pelaku usaha dengan bebas mencantumkan disclaimer dalam website tersebut.

Dengan demikian nampaknya pengaturan mengenai perlindungan hak-hak konsumen pada Undangundang No. 11 tahun 2008 tentang Informasi dan Transaksi Elektronik (UU ITE) masih belum diatur secara tegas. UU ITE sebagai ketentuan khusus karena ruang lingkupnya di dunia maya (cyberspace). Mengingat belum terdapatnya pengaturan khusus mengenai pencantuman disclaimer website dalam UU ITE, Oleh karena itu perlu pengkajian lebih mendalam mengenai "Perlindungan Hukum Bagi Konsumen Berkaitan Dengan Pencantuman Disclaimer Oleh 
Pelaku Usaha Dalam Situs Internet (website)."

\section{Rumusan Masalah}

1. Bagaimanakah pengaturan mengenai pencantuman disclaimer pada suatu situs internet (website) dalam perspektif hukum di Indonesia ?

2. Bagaimanakah bentuk perlindungan hukum bagi konsumen berkaitan dengan dicantumkanya disclaimer oleh pelaku usaha dalam situs internet (website)?

\section{Tujuan Penulisan}

a. Tujuan Umum

Untuk mengetahui pengaturan pencantuman disclaimer pada suatu situs internet (website)

b. Tujuan Khusus

Untuk meneliti perlindungan hukum bentuk perlindungan hukum bagi konsumen berkaitan dengan dicantumkanya disclaimer oleh pelaku usaha dalam situs internet (website) apabila terjadi kerugian dari konsumen tersebut.

\section{Landasan Teoritis}

Untuk menjawab rumusan masalah pertama mengenai pengaturan disclaimer pada suatu situs internet (website) di Indonesia, digunakan Teori Sistem Hukum dari Lawrence Friedman dan Teori tentang Azas-azas Pembentukkan Peraturan Perundang-undangan dari Lon L.Fuller. Sedangkan Untuk menjawab rumusan masalah kedua tentang perlindungan hukum terhadap konsumen berkaitan dengan dicantumkanya disclaimer oleh pelaku usaha dalam situs internet (website) digunakan Teori Keadilan dari Adam Smith dan Stakeholders Theory dari Milton Friedman's.

Teori Sistem Hukum menurut Lawrence M.Friedman mengandung komponen-komponen yaitu Struktur, Substansi dan Budaya Hukum. ${ }^{2}$ Yang termasuk dalam Struktur Hukum adalah institusi/lembaga yang diciptakan oleh sistem hukum salah satu diantara institusi tersebut

\footnotetext{
2 Lawrence M.Friedman,2009, Sistem Hukum Perspektif Ilmu Sosial (The Legal System : A Social Science Perspektive), (M. Khozim, Pentj), Nusa Media, Bandung, h. 12
} 
adalah peradilan dengan berbagai perlengkapannya. Substansi meliputi peraturan hukum, budaya meliputi nila dalam ada dalam masyarakat yang menjadi dasar dari hukum. Teori sistem hukum relevan untuk membahas rumusan masalah yang pertama, karena masih ada kekosongan pengaturan dari salah satu komponen sistem hukum yaitu pada substansi hukumnya pada UU No. 11 th. 2008 tentang Informasi dan Teknologi.

Teori tentang Azas-azas Pembentukkan Peraturan Perundangundangan dikemukakan oleh Lon L.Fuller. menurut Fuller, agar hukum (peraturan) berfungsi dengan baik, maka peraturan tersebut harus mematuhi atau mengikatkan diri secara ketat kepada 8 (delapan) syarat yang merupakan azas-azas dalam pembentukan Undang-undang. Syarat yang merupakan azas dalam pembentukkan peraturan perundangundangan menurut Lon I.Fuller salah satunya terdapat dalam angka 7 (tujuh) sebagaimana telah disebutkan adalah : mengenai konsisten di setiap waktu, Menurut Fuller, ketentuan bahwa hukum harus konstan/konsisten di setiap waktu tidak mutlak, karena hukum harus merespon perubahan yang terjadi di setiap waktu (Introducing such frequent changes in the rules).

Bila dikaitkan dalam perundangan tentang Informasi dan transaksi elektronik, khususnya menyangkut disclaimer. Menurut Fuller bahwa hukum harus dapat merespon perubahan yang terjadi di setiap waktu, dikaitkan dengan perundangan yang mengatur Informasi dan transaksi elektronik khususnya berkaitan dengan adanya disclaimer, artinya peraturan dalam bidang Informasi dan Transaksi Elektroik harus dapat mengakomodir segala macam kasus atau permasalahan yang menyangkut dunia internet yang timbul dari adanya perkembangan zaman agar tidak terjadi kekosongan hukum.

Teori Keadilan ${ }^{3}$ menurut Adam Smith mengenai konsep keadilan komutatif lebih mencakup korelasi diantara masyarakat khususnya Negara dengan perseorangan.

\footnotetext{
${ }^{3}$ Satjipto Rahardjo,2010, Teori Hukum Strategi Tertib Manusia Lintas Ruang dan Generasi, Genta Publishing, Yogyakarta, h. 44
} 
Perlindungan terhadap konsumen didasarkan pada keadilan komutatif tersebut.

Stakeholders theory lahir atas kritikan dan kegagalan shareholders theory atau Friedman's paradigm dalam upaya meningkatkan tanggung jawab perusahaan, yang terletak pada tanggung jawab tunggal manajemen terhadap stakeholders. Kegagalan tersebut mendorong munculnya stakeholders theory yang melihat shareholders sebagai bagian dari stakeholders itu sendiri. Stakeholders merupakan keterikatan yang didasari oleh suatu kepentingan tertentu ${ }^{4}$, membahas mengenai stakeholders theory berarti membahas hal-hal yang menyangkut tentang kepentingan dari berbagai pihak. Friedman's memberikan definisi tentang stakeholders ${ }^{5}$ yaitu :

$\begin{array}{lr}\text { "setiap kelompok } & \text { atau } \\ \text { individu } & \text { yang } \\ \text { mempengaruhi } & \text { atau } \\ \text { dipengaruhi oleh } & \text { suatu } \\ \text { pencapaian tujuan } & \text { suatu } \\ \text { perusahaan." } & \end{array}$

\footnotetext{
${ }^{4}$ Busyra Azheri, 2011,Corporate Social Responsibility (Dari Voluntary Menjadi Mandatory), PT.RajaGrafindo Persada, Jakarta, h.112

${ }^{5}$ Ibid
}

Dalam stakeholder theory, ada dua kategori yaitu kelompok primer dan kelompok sekunder. Konsumen termasuk dalam kelompok primer yang harus diperhatikan terlebih dahulu karena sangat menentukan keberhasilan suatu perusahaan dalam aktivitas usahanya oleh karena kelompok primer berinteraksi langsung dalam aktifitas bisnis perusahaan. ${ }^{6}$

\section{Metode Penelitian}

Penelitian ini termasuk dalam penelitian hukum normatif. ${ }^{7}$ Didalam penelitian hukum normatif, maka penelitian terhadap asas dan kaidah hukum yang menjadi pedoman dalam sikap dan prilaku masyarakat ${ }^{8}$ Penelitian ini dilakukan terhadap berlakunya asas-asas hukum dalam perlindungan hukum bagi konsumen berkaitan dengan dicantumkannya

\footnotetext{
${ }^{6}$ Dwi Kartini, 2009, Coorporate Social Responsibility Transformasi Konsep Sustainability Management dan Implementasi di Indonesia, Refika Aditama, Bandung, h.8

7 Soerjono Soekanto dan Sri Mamudji, 2001, Penelitian Hukum Normatif Suatu Tinjauan Singkat, PT RajaGrafindo Persada, Jakarta, h.14

${ }^{8}$ Nomensen Sinamo, 2009, Metode Penelitian Hukum, PT.Bumi Intitama Sejahtera, Jakarta, h. 107
} 
disclaimer oleh pelaku usaha dalam situs internet (website).

\section{HASIL DAN PEMBAHASAN}

\section{Tinjauan Umum Tentang Pencantuman Disclaimer Oleh Pelaku Usaha dalam Situs Internet (website)}

Disclaimer dalam website atau pernyataan pembebasan dari tanggung jawab diberikan dengan tujuan perlindungan bagi pelaku usaha pemilik website. Pengguna situs sebagau konsumen dianggap secara otomatis tanpa adanya bargaining position menerima syarat dan ketentuan yang berlaku pada website tersebut. ${ }^{9}$

Berdasarkan Hukum Indonesia keberadaan suatu klausula disclaimer yang ada di dalam situs internet (website) yang tidak dapat dinegosiasikan kepada konsumen terlebih dahulu dalam hukum perikatan termasuk dalam perjanjian standar. Tretel memberikan definisi perjanjian standar sebagai

9 Diana kusumasari, ,2011, status hukum pencantuman disclaimer, diakses dari URL : http://www.hukumonline.com, pada tanggal 12 September 2012 "syarat-syarat dalam perjanjian yang ditampilkan dalam bentuk formulir yang dicetak dalam bentuk baku yang digunakan untuk semua perjanjian yang sama jenisnya dan hanya berbeda sepanjang diperlukan oleh suatu keadaan."

Pelaku usaha yang menjalankan usahanya melalui sarana internet (online) dalam UU Nomor $11 \mathrm{Th}$. 2008 tentang Informasi dan Transaksi Elektronik maupun dalam Peraturan Pemerintah No. 82 Th. 2012 tentang penyelenggaraan Sistem dan Transaksi Elektronik termasuk dalam kategori Penyelenggara Sistem Elektronik (PSE). ${ }^{11}$ Pasal 1 angka 6 UU ITE memberikan pengertian tentang Penyelenggara Sistem Elektronik. ${ }^{12}$

Mengenai fitur yang wajib disediakan oleh Penyelenggara Sistem Elektronik dan sesuai dengan karakteristik sistem elektronik yang

10 G.H Treitel, 1995, The law of contract, $9^{\text {th }}$ Edition, Sweet \& Maxwell Ltd, London, h.196

${ }^{11}$ Teguh Arifiyadi, 2013, Sertifikasi Pelaku Usaha Online, diakses dari :URL : www.hukumonline.com, pada tanggal 9 Oktober 2013

12 Penyelenggara Sistem Elektronik sebagai pemanfaatan sistem elektronik oleh penyelenggara Negara, orang, badan usaha, dan/atau masyarakat 
digunakan diatur dalam Pasal $26 \mathrm{PP}$ No. 82 Th. 2012. ${ }^{13}$ Kewajiban Penyelenggara Sistem Elektronik menerapkan tanggung jawab terhadap resiko berkaitan dengan kerugian yang diderita konsumen. Pelaku usaha penyelenggara transaksi elektronik juga memiliki kewajiban berdasarkan Pasal 49 PP No. 82 Th. 2012 salah satunya adalah konsumen wajib diberikan batas waktu pengembalian barang.

Dalam transaksi bisnis melalui internet menimbulkan beberapa masalah yuridis ${ }^{14}$, salah satunya yang menarik yaitu mengenai pembebasan tanggung jawab. Di dalam suatu situs internet (website) disadari/tidak oleh masyarakat yang mengunjungi suatu website, baik itu website yang menyediakan layanan informasi maupun layanan jual beli secara

13 Fitur wajib berupa fasilitas untuk melakukan koreksi, membatalkan perintah, memberikan konfirmasi atau rekonfirmasi, memilih meneruskan atau berhenti melaksanakan aktivitas berikutnya, melihat informasi yang disampaikan berupa tawaran kontrak atau iklan, mengecek status berhasil atau gagalnya transaksi dan membaca perjanjian sebelum melakukan transaksi.

14 Niniek Suparni, 2009, Cyberspace Problematika \& Antisipasi Pengaturannya, Sinar Grafika, Jakarta, h.52 elektronik (e-commerce), terdapat klausula mengenai pembebasan tanggung jawab tersebut yang diciptakan oleh pemilik situs sebagai pelaku usaha dengan tujuan agar supaya jelas bagi para pihak akan batas dari tanggung jawab masingmasing pihak.

Dalam prakteknya di Indonesia dalam suatu situs internet (website), baik itu website penyedia layanan informasi elektronik maupun transaksi jual beli pihak pelaku usaha pemilik situs mencantumkan suatu klausula eksemsi yang disebut disclaimer tersebut yang mana letaknya di dalam website tidak langsung muncul dilayar (screen) monitor ketika konsumen internet membuka suatu website. Biasanya disclaimer dari suatu situs terdapat dibagian bawah tampilan situs yang penulisannya menggunakan ukuran font lebih kecil daripada tulisan utama dari situs tersebut dan ada juga situs yang langsung menggabungkan disclaimer didalam suatu term and condition suatu situs internet. Dari segi isinya, pada disclaimer isinya sudah ditentukan secara sepihak oleh penyelenggara 
sistem elektronik/ pelaku usaha. Pengguna sistem elektronik/ konsumen tidak dapat menegosiasikan isinya karena perjanjian sudah tercetak dilayar. Sebagai contoh isi dari disclaimer dalam website, pertama, disclaimer pada situs penyedia TV streaming yang berbunyi

"None of the streams are hosted on this server, please contact ustream tv, vogulus, selfcast or justin tv directly regarding this stream copyright"

Dapat diketahui bahwa tidak ada satupun aliran host/pemilik pada server ini, silahkan langsung menghubungi ustream $t v$, vogulus, selfcast atau justin tv mengenai hak cipta siaran ini. Mengacu kepada disclaimer tersebut, yang merupakan sebuah website penyedia TV streaming, ada sedikit ketidaksesuaian terhadap disclaimer yang mereka cantumkan, secara sederhana logikanya adalah apakah mungkin web TV streaming tersebut tidak bertanggung jawab atas apa yang ditayangkan, maupun di embed (dilekatkan), meskipun content dan server-nya itu berasal dari website lain. ${ }^{15}$ Tentu saja disini sangat jelas dilihat bahwa penyelenggara sistem elektronik pada situs tersebut ingin mengalihkan tanggung jawabnya. Contoh yang kedua, disclaimer pada Online Shop Indonesia, menyebutkan "Barang tidak dapat di retur dengan alasan apapun dan konsumen yang membatalkan pesnannya akan di masukkan dalam daftar hitam konsumen/blacklist." Hal tersebut tentu saja bertentangan juga dengan ketentuan mengenai klausula baku dalam UUPK dan Pasal 4 UUPK mengenai hak konsumen salah satunya hak mendapatkan ganti rugi.

\section{Pengaturan Disclaimer Dalam}

Perspektif Hukum Di Indonesia

Dalam UU No.11 Th.2008 ini juga menganut asas kebebasan berkontrak yang terdapat dalam Pasal 1338 KUHPerdata yang sesuai dengan kesepakatan para pihak sesuai dengan Pasal 1320 KUHPerdata. Asas kebebasan berkontrak menyatakan bahwa setiap

\footnotetext{
${ }^{15}$ Mustadafin, 2012, Standar Ganda Copyright pada Website, diakses dari URL : http://www.kaskus.co.id, pada tanggal 20 Juni 2012
} 
orang dapat membuat kontrak atau perjanjian yang substansi dan macam apapun asal tidak bertentangan dengan perundangan, kesusilaan dan ketertiban umum. ${ }^{16}$ Selanjutanya kebebasan berkontrak juga memberikan kebebasan untuk menentukan substansi serta persyaratan dari suatu perjanjian asalkan tidak bertentangan dengan peraturan perundang-undangan ${ }^{17}$, dapat disimpulkan dari Pasal 1337 KUHPerdata bahwa sebab disebut terlarang jika dilarang oleh undangundang. Hal ini juga yang menjadi dasar pemikiran mengapa pemilik situs di internet mencantumkan substansi daripada suatu disclaimer dengan bebas sesuai dengan kehendaknya, namun yang menjadi permasalahan adalah mengenai tidak adanya kesepakatan kedua belah pihak karena isi dari disclaimer tidak dinegosiasikan terlebih dahulu dengan masing-masing konsumen. Dengan konsumen setuju untuk

${ }^{16}$ Ridwan Syahrani, 1985, Seluk beluk dan Asas-asas Hukum Perdata, Alumni, Bandung, h.212

${ }^{17}$ Herlien Budiono, 2010, Ajaran Umum HukumPerjanjian dan Penerapannya di bidang kenotariatan, PT Citra Aditya Bakti, Bandung, h.31 berbelanja dan memanfaatkan isi suatu website itu juga berarti konsumen telah setuju dengan seluruh syarat yang telah pemilik situs cantumkan dalam disclaimer, sedangkan letak dari disclaimer pun terkadang tidak terbaca dan tidak disadari konsumen oleh karena letaknya dibawah homepage website.

Pasal 19 UU No.11 Th. $2011^{18}$ yang secara tersirat memperbolehkan segala bentuk klausula apapun di dalam sistem elektronik asalnya para pihak sepakat. Klausula pengalihan tanggung jawab dalam klausula baku disebut juga klausula eksonerasi. Treitel mendefinisikan klausula eksonerasi sebagai " $a$ clause excluding or limitation liability" dapat diketahui bahwa sebuah klausula yang meniadakan atau membatasi tanggung jawab. ${ }^{19}$ Pencantuman klausula eksonerasi ini dilarang berdasarkan Pasal 18 ayat $(1)^{20}$ UUPK. Kemudian mengenai

${ }^{18}$ Menyebutkan bahwa "Dalam
melakukan Transaksi Elektronik Para Pihak
harus menggunakan Sistem Elektronik yang
disepakati".
${ }^{19}$ Ibid
${ }^{20}$ Pelaku usaha dalam menawarkan
barang dan/atau jasa yang ditujukan untuk


letak klausula baku yang sulit untuk dilihat dan dimengerti diatur dalam Pasal 18 ayat (3) UUPK.

Berkaitan dengan pencantuman disclaimer dalam situs internet (website) belum diatur secara khusus didalam Perundangan di Indonesia. Apabila ditinjau dari pengertian klausula baku yang telah dijelaskan dalam pembahasan sebelumnya, maka substansi dari disclaimer dalam website termasuk dalam ketentuan klausula baku yang dilarang. UUPK tidak mengatur pencantuman klausula baku dalam lingkup transaksi secara elektronik. Peraturan yang mengatur ruang lingkup Transaksi Elektronik di Indonesia adalah UU No. 11 Th. 2008. Oleh karena itu masih terdapat kekosongan norma dalam pengaturan

diperdagangkan dilarang membuat dan/atau mencantumkan kalusula baku pada setiap dokumen dan/atau perjanjian apabila: menyatakan pengalihan tanggung jawab pelaku usaha, menyatakan bahwa pelaku usaha berhak menolak menyerahkan kembali barang yang dibeli konsumen, menyatakan bahwa pelaku usaha berhak menolak penyerahan kembali uang yang dibayarkan atas barang dan/atau jasa yang dibeli oleh konsumen, mengatur perihal pembuktian atas hilangnya kegunaan barang atau pemenfaatan jasa yang dibeli oleh konsumen. disclaimer dalam situs internet (website).

Berkaitan dengan adanya kekosongan norma harus diisi dengan suatu pengaturan dalam perundang-undangan. Suatu pembentukan peraturan perundangundangan berpedoman dengan Teori tentang Azas-azas Pembentukkan Peraturan Perundang-undangan dimana menurut Fuller hukum harus dapat merespon setiap perubahan yang terjadi kehidupan masyarakat. Jadi fenomena kemunculan disclaimer dalam situs internet (website) harus direspon oleh hukum melalui pengaturan secara tegas agar dapat melindungi seluruh masyarakat dalam hal ini sebagai konsumen. Apa yang dikemukakan Fuller juga berkaitan dengan Teori Sistem Hukum dari Lawrence M. Friedman yang mengemukakan bahwa pembentukkan suatu perundangundangan juga sangat dipengaruhi oleh sistem hukum suatu Negara. Jika tidak ada substansi hukum yang merupakan peraturan perundangunangan maka tidak ada pedoman yang akan digunakan bagi lembaga pemerintahan yang termasuk dalam 
struktur hukum untuk

stabilitas sosial yang akan menindaklanjuti permasalahan yang timbul di dalam kehidupan masyarakat yang dimana masyarakat merupakan perwujudan dari suatu budaya hukum.

3. Perlindungan Hukum bagi Konsumen berkaitan dengan pencantuman Disclaimer dalam Situs Internet (website) oleh Pelaku Usaha

Seberapa besar dukungan stakeholder kepada perusahaan menentukan seberapa besar pula kesuksesan suatu perusahaan tersebut Dukungan dari stakeholder harus selalu diperoleh oleh suatu perusahaan hidup suatu perusahaan untuk mengukur sebagian besar perusahaan tersebut dapat beradaptasi. Di dalam pelaksanaan kegiatan bisnis di internet secara online tentu saja konsumen sebagai stakeholder harus diperhatikan oleh pelaku usaha yang memasarkan produknya melalui situs internet (website). Hal ini diperlukan agar kegiatan bisnis elektronik dapat dibangun berdasarkan konsep kebermanfaatan yang saling menguntungkan dan adil. Suatu menunjang kegiatan bisnis akan tercipta jika suatu keadilan terwujud. Tidak lengkap jika suatu keadilan tidak diikuti dengan adanya hukum.

Untuk melindungi hak-hak masyarakat agar tercipta suatu keadilan tentu saja dibutuhkan suatu upaya melalui perlindungan hukum. Dalam kaitannya dengan perlindungan hukum bagi konsumen internet tersebut, menurut Philipus M.Hadjon ${ }^{21}$ bahwa dapat diuraikan menurut jenis perlindungan hukum ada 2 bentuk yaitu perlindungan hukum preventif dan represif. Perlindungan preventif dalam hal pencantuman disclaimer ini berfungsi untuk mencegah agar konsumen berada dipihak yang lemah dan tidak semata-mata dirugikan.

Perlindungan bagi hak konsumen yang telah ada dalam UU No. 11 Th. 2008 diatur dalam Bab III mengenai Informasi, dokumen dan tanda terima elektronik diatur dalam

\begin{tabular}{llrr}
\hline 21 Philipus M. & Hadjon, & 2007, \\
Perlindungan Hukum & Bagi & Rakyat \\
Indonesia, Percetakan & M2 & Print, & Edisi \\
Khusus, Surabaya, h.3 & &
\end{tabular}


Pasal 9 UU ITE ${ }^{22}$. Selanjutnya, mengenai sertifikasi bagi setiap website di Indonesia diatur dalam Pasal 10 UU ITE ${ }^{23}$.

Lembaga Sertifikasi Keandalan (LSK) ${ }^{24}$ ini diatur dalam PP No. 82 Th. 2012 Di Indonesia secara formal belum ada satupun LSK yang diakui dan disahkan oleh pemerintah. Beberapa contoh LSK asing yang telah ada secara resmi adalah GeoTrust, Hacker Safe, Trust Guard, VerySign, McAfee Secure dan Trustweb. Tentu saja jika LSK ini terwujud dan sistem transaksi elektronik di dunia maya (cyberspace) tetap diawasi dengan jujur, maka konsumen akan merasa

\footnotetext{
${ }^{22}$ Pasal 9 UU ITE dalam mengatur mengenai kewajiban pelaku usaha dalam menawarkan produknya melalui sistem elektronik (dalam hal ini internet) harus menyediakan secara lengkap dan benar berkaitan dengan syarat kontrak, produsen dan produk yang ditawarkan

${ }^{23}$ Pasal 10 UU ITE mengenai setiap pelaku usaha yang menyelenggarakan transaksi elektronik dapat disertifikasi oleh Lembaga Sertifikasi Keandalan

${ }^{24}$ Lembaga independen yang dibentuk oleh profesional yang diakui, disahkan, dan diawasi oleh Pemerintah dengan kewenangan mengaudit dan mengeluarkan Sertifikat Keandalan dalam Transaksi Elektronik (Pasal 1 angka 24 PP PSTE).
}

lebih tenang untuk memanfaatkan dunia internet untuk bertransaksi dan mencari informasi.

Perlindungan hukum represif dalam hal penyelesaian pada saat stelah terjadi sengketa, dibagi lagi menjadi dua yaitu melalui jalut litigasi dan non litigasi.

Melalui jalur litigasi :

Setiap orang tersebut sebagai konsumen internet yang mengalami kerugian dapat mengajukan gugatan terhadap peyelenggara sistem elektronik yaitu pelaku usaha yang memiliki situs internet. Jika yang dirugikan adalah masyarakat sesuai Pasal 38 ayat (2) UU ITE juga memperbolehkan untuk diadakannya gugatan secara perwakilan terhadap pihak penyelenggara sistem elektronik yang berakibat merugikan masyarakat. Dalam Pasal 45 UU ITE $^{25}$ memberikan ancaman pidana terhadap website yang menyebarkan berita bohong yang mengakibatkan kerugian konsumen (Pasal 28 ayat 1 UU ITE).

\footnotetext{
${ }^{25}$ Hukuman paling lama 6 (enam) tahun dan denda paling banyak Rp.1.000.000.000,(satu miliar rupiah).
} 
Selanjutnya jika dikaitkan dengan UU Perlindungan Konsumen (UUPK) Pasal 18 ayat (1) dan ayat (2) UUPK, Pasal 18 ayau (3) UUPK menyatakan batal demi hukum setiap klausula baku yang telah ditetapkan oleh pelaku usaha pada dokumen yang memuat ketentuan yang dilarang dalam Pasal 18 ayat (1) UUPK. Ini juga berarti suatu klausula baku dalam transaksi secara langsung diluar lingkup dunia maya yang memuat ketentuan mengenai klausula baku yang dilarang dalam Pasal 18 ayat (1) Undang-undang Perlindungan Konsumen atau yang memiliki format sebagaimana dilarang dalam Pasal 18 ayat (2) UUPK dianggap tidak pernah ada dan mengikat para pihak, namun UUPK hanya mengatur ruang lingkup transaksi konvensional (dunia nyata) bukan transaksi secara elektronik (dunia maya). Jadi disini belum jelas mengenai konsekuensi pengaturan disclaimer dalam suatu website.

Melalui jalur non litigasi :

Penyelesaian sengketa yang dapat dilakukan secara damai dengan jalan negosiasi, mediasi dan konsiliasi. Penyelesaian sengketa juga dapat dilakukan melalui lembaga arbitrase, hal ini termasuk dalam penyelesaian sengketa secara adversarial yang melibatkan suatu lembaga. Arbitrase pada dasarnya berbentuk lembaga non Negara atau swasta untuk menyelesaiakn sengketa secara cepat.

Lembaga alternatif penyelesaian sengketa di Indonesia untuk menyelesaikan sengketa konsumen di dunia nyata dapat digunakan adalah Badan Penyelesaian Sengketa Konsumen (BPSK). Lembaga penyelesaian di luar pengadilan yang dilaksanakan oleh BPSK ini memang dikhususkan bagi pelaku usaha dan konsumen yang meliputi jumlah nilai yang kecil tetapi dalam pelaksanaannya tidak ada batasan nilai pengajuan gugatan, sehingga dimungkinkan gugatan konsumen meliputi jumlah nilai kecil sampai besar.

Dapat diperhatikan bahwa UUPK belum dapat melindungi konsumen dalam transaksi elektronik, karena UUPK mempunyai keterbatasan pengertian tentang pelaku usaha yang wilayah usahanya hanya di 
wilayah Indonesia. Padahal transaksi elektronik merupakan model perdagangan yang dapat melintasi wilayah hukum suatu Negara. Untuk mempermudah penyelesaian sengketa dalam transaksi elektronik dalam perkembangan saat ini juga muncul penyelesaian sengketa secara online (online dispute resolution/ODR). ODR pada dasarnya sama dengan mekanisme arbitrase scara konvensional namun medianya saja yang berbeda dimana ODR menggunakan media internet sebagai media untuk menyelesaikan sengketa. Demi keadaan tertentupun demi kelancaran ODR dapat mempertemukan para pihak yang bersengketa. Berdasarkan Pasal 4 ayat (3) UU No.30 Tahun $1999^{26}$ diberikan kemungkinan dipergunakannya e-mail dalam proses penyelesaian sengketa meskipun baru dalam tahap penyampaian surat. Namun di

\footnotetext{
${ }^{26}$ Pasal 4 ayat (3) UU No. 30 Tahun 1999 menyatakan "Dalam hal disepakati penyelesaian sengketa melalui arbitrase terjadi dalam bentuk pertukaran surat, maka pengiriman teleks, telegram, faksimili, $e$ mail, atau dalam bentuk sarana komunikasi lainnya, wajib disertai dengan suatu catatan penerimaan oleh para pihak"
}

Indonesia sampai saat ini belum diterapkan arbitrase online tersebut.

\section{PENUTUP}

\section{Simpulan}

Berdasarkan pembahasan terhadap penelitian sebagaimana dikemukakan , kesimpulan yang dapat ditarik adalah sebagai berikut :

1) Apabila ditinjau dari UU No.8 Th. 1999 tentang Perlindungan Konsumen, maka dalam transaksi di dunia nyata disclaimer dapat dikategorikan sebagai klausula eksonerasi yang dilarang dalam Pasal 18 ayat (1) UUPK. Akan tetapi terjadi kekosongan norma di dalam UU No.11 Th. 2008 tentang Informasi dan Transaksi Elektronik (UU ITE) yang secara khusus (lex specialis derogate legi generali) mengatur kegiatan di dunia maya (cyberspace). Dalam UU ITE belum diatur mengenai kriteria-kriteria substansi yang dapat dicantumkan pada suatu disclaimer dalam situs internet (website) agar dapat melindungi hak-hak konsumen.

2) Bentuk perlindungan hukum terhadap konsumen mengacu pada 
pencantuman disclaimer dalam website sebagai suatu bentuk klausula baku, masih lemah. Adapun saat ini perlindungan hukum konsumen yang dapat diberikan, ada 2 (dua) yaitu secara preventif yakni disyaratkan dengan adanya suatu Lembaga Sertifikasi Keandalan (LSK) berdasarkan PP. No. 82 Th. 2012 tentang Penyelengaraan Sistem dan Transaksi Elektronik yang merupakan turunan dari Pasal 10 ayat (2) UU No.11 Th. 2008 tentang Informasi dan Transaksi Elektronik dan secara represif penyelesaian sengketa dalam jalur litigasi dilakukan melalui pengajuan gugatan perdata dan dikenakan sanksi pidana berdasarkan UU ITE melalui jalur Non Litigasi yang ideal dengan filosofi lahirnya transaksi elektronik dengan media situs internet (website) adalah melalui Alternatif Penyelesaian Sengketa salah satunya melalui jalur Arbitrase.

\section{Saran}
a. Pertama untuk pemerintah melalui
Departemen

Komunikasi dan Informasi (Depkominfo) segera mengambil tindakan dalam rangka kepastian pengaturan yaitu peraturan Perundangundangan tentang Informasi dan Transaksi Elektronik materi yang diatur haruslah jelas dan lengkap. Terutama mengenai kriteria dari substansi dari suatu disclaimer dalam situs internet (website) yang melindungi hakhak konsumen.

b. Dalam upaya memberikan Perlindungan hukum yang maksimal terhadap konsumen disarankan bagi Pemerintah disarankan agar dipertegasnya syarat-syarat pendaftaran bagi Lembaga Sertifikasi Keandalan (LSK) untuk memberikan sertifikasi untuk setiap situs internet (website) sehingga konsumen dapat melihat sertifikat keandalan di website milik pelaku usaha dan agar segera dibentuk arbitrase online resmi di Indonesia untuk memudahkan para pihak dalam penyelesaian sengketa secara online tersebut. 
DAFTAR PUSTAKA

\section{BUKU}

Azheri, Busyra 2011, Corporate Social Responsibility (Dari Voluntary Menjadi Mandatory), Jakarta : PT.RajaGrafindo Persada

Budiono, Herlien, 2010, Ajaran Umum HukumPerjanjian dan Penerapannya di bidang kenotariatan, Bandung : PT Citra Aditya Bakti

Friedman , Lawrence M.,2009, Sistem Hukum Perspektif Ilmu Sosial (The Legal System : A Social Science Perspektive), (M.Khozim, Pentj), Bandung : Nusa Media

Hadjon, Philipus M. , 1987, Perlindungan Hukum Bagi Rakyat Di Indonesia, Surabaya : PT Bina Ilmu

Kartini, Dwi, 2009, Coorporate Social Responsibility Transformasi Konsep Sustainability

Management dan Implementasi di Indonesia, Bandung : Refika Aditama

Rahardjo, Satjipto, 2010, Teori Hukum Strategi Tertib Manusia Lintas Ruang dan Generasi, Yogyakarta : Genta Publishing

Sinamo ,Nomensen, 2009, Metode Penelitian Hukum, Jakarta : PT.Bumi Intitama Sejahtera.
Soekanto, Soerjono dan Sri Mamudji, 2001, Penelitian Hukum Nornatif Suatu Tinjauan Singkat, Jakarta : PT RajaGrafindo Persada.

Syahrani, Ridwan , 1985, Seluk beluk dan Asas-asas Hukum Perdata, Bandung : Alumni

Treitel, G.H., 1995, The law of

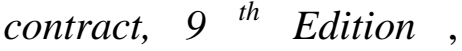
Sweet \& Maxwell Ltd, London

Turban, Efraim, et.al., ,2010, Electronic commerce 2010 (a managerial perspective) sixth edition, USA : Pearson.

\section{Artikel Internet}

Diana Kusumasari, 2011, status hukum pencantuman disclaimer, diakses dari URL http://www.hukumonline.c om, pada tanggal 12 September 2012

Mustadafin, 2012, Standar Ganda Copyright pada Website, diakses dari : http://www.kaskus.co.id, pada tanggal 20 Juni 2012

Teguh Arifiyadi, 2013, Sertifikasi Pelaku Usaha Online, diakses dari :URL : www.hukumonline.com , pada tanggal 9 Oktober 2013 
III Peraturan Perundangundangan

Undang-undang Dasar Negara Republik Indonesia 1945

Kitab Undang-Undang Hukum Perdata (KUHPerdata)

Undang-undang Nomor 8 Tahun 1999 Tentang Perlindungan Konsumen

Undang-undang Nomor 11 Tahun 2008 Tentang Informasi dan Transaksi Elektronik.

Peraturan Pemerintah Nomor 82 Tahun 2012 Tentang
Penyelenggaraan Sistem dan Transaksi Elektronik.

\section{Biodata singkat penulis:}

Nama lengkap dengan gelar :

Ni Putu Ria Dewi Marheni, SH.,MH.

Alamat rumah :

Jl.P.Kawe Gg.Kartika II / 1 Denpasar HP :

081808121214

e-mail :

puturiadewimarheni@gmail.com 